Self-perceived preparedness of final year dental students in a developing country-A multi-institution study.

\title{
Urzinger, Sebastian
}

http://hdl.handle.net/10026.1/12260

10.1111/eje.12389

European Journal of Dental Education

Wiley

All content in PEARL is protected by copyright law. Author manuscripts are made available in accordance with publisher policies. Please cite only the published version using the details provided on the item record or document. In the absence of an open licence (e.g. Creative Commons), permissions for further reuse of content should be sought from the publisher or author. 
Accepted Proof

Title:

Self-perceived Preparedness of Final Year Dental Students in a Developing Country- A multi-institution Study

K Ali ${ }^{1}$, J Cockerill², D Zahra ${ }^{3}$, HS Qazi ${ }^{4}$, U Raja ${ }^{5}, \mathrm{~K}$ Ataullah $^{6}$

Acceptance Date: $20^{\text {th }}$ July 2018

DOI: HTTPS://DOI.ORG/10.1111/EJE.12389 


\section{Abstract}

Aims: To evaluate the self-perceived preparedness to practice of final year dental undergraduate students in three dental institutions.

Methods: Dental undergraduate students in their final year from three dental institutions in Pakistan were invited to participate in an online study to assess self-perceived preparedness using a validated preparedness assessment scale.

Results: In total 134 students responded to the questionnaire yielding a response rate of $72 \%$. Students felt adequately prepared to carry out several clinical procedures including clinical assessment, fillings, tooth extractions and communication skills. However, perceived preparedness was low in the students' ability to undertake intraoral radiographs, treatment planning, crowns, multi-rooted endodontics, research skills, referral for suspected oral cancer and raising concerns regarding inappropriate behaviour of colleagues.

Conclusions: This is the first study which investigates the self-perceived preparedness of final year undergraduate dental students in Pakistan. The results show that the selfperceived preparedness of final year students was satisfactory for a range of clinical and affective skills. However, several areas of weaknesses were identified which underscore the need for additional training and consolidation. 


\section{Introduction}

The ultimate goal of education and training of undergraduate dental students is to impart the knowledge, skills, and attitudes to prepare them for independent clinical practice in a safe and effective manner (1-3). Dental students are expected to demonstrate competence in range of clinical operative procedures as well as skills in communication, team-working, management, leadership and professionalism.

Preparedness of undergraduate students may be influenced by a variety of factors including: curriculum design; teaching methods; educational environment; clinical training model; and assessment methods (4-8). Previous studies on dental students show inconsistencies in the skill-set of undergraduate students and new graduates and it may not always be possible to demonstrate competence in all core skills expected from students at the point of graduation (4, 9-11). Longitudinal evaluation of students against the learning outcomes of an undergraduate dental programme may allow dental educators to identify areas of weaknesses and address them appropriately through additional education, training and consolidation (12).

Several studies exploring the skills and attributes of undergraduate dental students in Europe, the USA, and other countries are reported in the literature (12-15). However, little work has been published on the preparedness of dental graduates from developing countries. Given that overseas-qualified dentist contribute to the dental workforce in developed countries; it is important to develop an understanding of the preparedness of dental graduates from less developed countries (16-18). With this aim, this study was undertaken to investigate the self-perceived preparedness of final year dental undergraduate students in Pakistan. 


\section{Methods}

Following approval by the institutional research ethics committee, dental undergraduate students from three institutions in Pakistan were invited to participate in an online study. Purposive sampling was used and final year dental students after completion of the first six months of the academic year were included in this study. A reminder was sent after two weeks along with the URL for the study.

Self-perceived preparedness of final year dental students was investigated using a previously validated scale, the Dental Undergraduates Preparedness Assessment Scale - DU-PAS (19). DU-PAS is a measurement tool that has been demonstrated to evaluate a broad range of skills and attributes expected from dental students at the time of graduation. The questionnaire consisted of two parts, with Part A investigating preparedness in clinical procedures (24 items) and Part B investigating preparedness relating to cognition, communication, and professionalism skills (26 items). The structure of the 50 -item inventory as well as the scoring of response categories is shown in the Appendix.

Data Analysis

1. Analyses were conducted using the R statistical environment for Windows (R Core Team, 2015).

2. Responses of 'No experience' were allocated a score of zero; 'With verbal/practical help' or 'Mostly' a score of one and 'On my own, independently' or 'Always' a score of two.

Data collection and analysis were completed in approximately eight months. 


\section{Results}

In total 134 final year dental students responded to the online questionnaire, yielding a response rate of $72 \%$. All participants were in the $20-25$ years age group. Complete responses were provided by 124 participants including 106 females (85.5\%) and 18 males (14.5\%). The remaining 10 participants with incomplete responses were excluded from the following analyses.

The total score for the preparedness scale ranged from 0 to 100 . The mean score for the participants in this study was 65.60 (SD \pm 10.82 ) with a range of 39.00 to 94.00 .

The responses to Part A of the questionnaire are shown as percentage proportions of each response type in Table 1; the items are ordered by the 'No experience' column in a descending order. Across the 24 questions relating to clinical procedures, more than $10 \%$ of students felt they had no experience for six of the procedures, with more than $50 \%$ of the students feeling they had no experience for three of these (A5, A20, A22). All students felt they had some experience for six (25\%) of the procedures (A1, A14, A16, A17, A18 and A24).

The responses to Part B of the questionnaire are shown as percentage proportions of each response type in Table 2; the items are ordered by the 'No experience' column in a descending order. Across the 26 questions in Part B, more than $10 \%$ of students felt they had no experience for six of the skills, with more than $50 \%$ of the students feeling they had no experience for one of these (B30). All students felt they had some experience for four (15.4\%) of the skills (B36, B40, B43 and B50). 


\section{Discussion}

This is the first study aimed at investigating the cognitive attributes, clinical, and affective skills of undergraduate dental students from a developing Asian country. Dental graduates from South East Asia make a notable contribution to the dental workforce in the United Kingdom and beyond $(17,18)$. Little, if any, information is available in the published literature about Pakistani graduates and this study provides useful and timely insights into the teaching and training of dental graduates from this country.

The mean total score of the participants in this study was 65.60. A mean score of 74 was reported in previous work exploring perceived preparedness of final year dental undergraduate students from the UK (12). These results indicate that the Pakistani graduates feel less prepared than those in the UK.

Regarding the clinical skills, over $70 \%$ of the participants in this study reported competence in obtaining a medical history; obtaining a valid consent for treatment; administering inferior alveolar nerve blocks; caries removal; and providing tooth fillings using amalgam and tooth-coloured materials independently. These findings are similar to those reported in studies on graduates from Europe $(4,12-14)$.

A high proportion of students (81.5\%) perceived themselves to be prepared in undertaking tooth extractions. This may be explained by the availability of large numbers of patients requiring tooth extractions. Most dental institutions in Pakistan require each undergraduate student to perform approximately 100 extractions prior to graduation which accounts for this level of perceived preparedness. 
The participants reported inadequate experience in undertaking intra-oral radiographs; only $7.3 \%$ students felt prepared in undertaking bitewing radiographs while $25 \%$ felt competent in undertaking periapical radiographs. In contrast, majority of students from UK reported competence in undertaking intra-oral radiographs (12). The lack of competence reported by the Pakistani graduates may be explained by deficient training in undertaking routine dental radiography. In most dental institutions, dental students have limited opportunities to undertake radiographs themselves and often rely on radiography department for the same. Moreover, a lack of consistent summative assessment of students on undertaking radiographs and this may contribute further to their lack of competence. Finally, financial constraints in developing countries may limit availability of teaching staff and equipment.

The participants in this study were less confident in comprehensive treatment planning to address all treatment needs of their patients and over $70 \%$ did not feel confident in independent treatment planning. Deficiencies in treatment planning skills are widely reported in studies on dental students and new graduates in Europe and the USA (12, 15). Perhaps, departmental model of clinical training limits the opportunities available to undergraduate students to carry out comprehensive treatment planning to address and prioritise multiple treatment needs of patients in an appropriate order. It may be helpful for dental educators in Pakistan to consider tailored courses in comprehensive dental care like those introduced in other dental schools to enhance students' competence in treatment planning (20).

Students felt least prepared to undertake endodontics in multi-rooted teeth and providing crowns. Deficiencies in endodontic skills of undergraduate students have been reported previously $(12,21,22)$. Moreover, the students also felt under-prepared in the provision of partial dentures. These findings may be attributed to lack of adequate 
experience in the design and delivery of cast partial dentures. Observations from the dental school settings in Pakistan suggest that the students' experience in partial dentures is largely limited to acrylic dentures and they may not receive adequate training in the construction of cast partial dentures.

This study has identified several areas of under-confidence in the clinical skills of final year students close to the point of graduation. However, it needs to be reiterated that competence of undergraduates only represents a point on a continuum and their preparedness needs to be measured using an appropriate "grain-size" $(23,24)$. It is widely reported that dental students may lack competence in complex clinical procedures such as multi-rooted endodontics and tooth preparations for extra-coronal restorations and they may need further consolidation after graduation to develop their skills $(25,26)$. However, it is unusual, relative to dental graduates in developed countries, that the participants reported lack of preparedness in undertaking radiographs and performing non-surgical periodontal treatments. It is hoped that the results reported here will be of use to dental educators in Pakistan, facilitating recognition of areas in the clinical training of their students in which additional support, reassurance, and where necessary, training, may be needed.

The participants generally felt prepared to communicate appropriately and effectively with their patients and colleagues. However, they felt under-prepared in raising concerns about inappropriate behaviour of colleagues. Anecdotal evidence from the dental school environments in Pakistan suggests written policies on raising concerns may not be available. This study highlights the need to have appropriate guidelines and training of students as well as academic staff. It is suggested that dental educators may use simulated scenarios to impart a broad-based structured training in affective skills. 
The participants reported low scores on the ability to refer suspected oral cancer. Studies from the UK and USA also highlight a perceived lack of knowledge and skills among dental students to identify oral cancer $(12,27,28)$. The results of this study reiterate the need to further improve the teaching and training of dental students in this domain. Regular placement of students on specialist clinics in maxillofacial surgery may serve to provide a structured exposure to cancer patients to improve their understanding of the clinical presentation, and management principles which underpin cancer care.

The participants felt under-prepared in using an evidence-informed approach in their clinical practice; evaluating new dental materials; and interpreting the results of research studies. Similar findings are reported in other studies and undergraduate dental students generally lack knowledge and skills in evidence-based practice $(12,29$, 30). Given the rapid technological advancements and growing number of commercial stakeholders in dentistry, it is vital that dental educators identify effective learning strategies so that students are able to incorporate an evidence-based approach in their clinical practice.

One of the limitations of this study is that the sample includes participants from only three dental institutions in Pakistan and may not be representative of the entire country with over 50 dental schools. Moreover, the findings are based on self-perceived preparedness of the students and may potentially be biased by unrelated or extraneous experiences. Evidence from previous studies self-perceived competence scores by the students may have a low reliability $(31,32)$. Therefore, it is prudent for dental institutions to compare self-assessment by the students with the assessment by dental educators and use it to identify gaps in knowledge and skills. Nevertheless, feedback 
from the students is vital to inform further curriculum development and refinement of teaching and training to enhance the educational experience of the students (33). 


\section{Conclusions}

This is the first study which investigates the self-perceived preparedness of final year undergraduate dental students in Pakistan. The results show that the self-perceived preparedness of final year students was satisfactory for a range of clinical and affective skills. However, several areas of weaknesses were identified which underscore the need for additional training and consolidation. The study also provides a broad-based comparison between final year Pakistani students with dental students from developed countries. 
Table 1: Summary of response proportions as percentages for Part A

*Items are ordered by the 'No experience' column in descending order.

\begin{tabular}{|c|c|c|c|c|}
\hline Item & Question & $\begin{array}{c}\text { No } \\
\text { experience } \\
(\%)\end{array}$ & $\begin{array}{c}\text { With } \\
\text { help } \\
(\%)\end{array}$ & $\begin{array}{c}\text { On my } \\
\text { own } \\
(\%)\end{array}$ \\
\hline A5 & I am able to undertake bitewing radiographs & 66.9 & 25.8 & 7.3 \\
\hline A20 & $\begin{array}{l}\text { I am able to perform endodontic treatment on multi } \\
\text { rooted teeth appropriately }\end{array}$ & 51.6 & 40.3 & 8.1 \\
\hline A22 & I am able to provide mechanically sound partial dentures & 50.8 & 24.2 & 25.0 \\
\hline A21 & $\begin{array}{l}\text { I am able to provide crowns using principles of tooth } \\
\text { preservation }\end{array}$ & 41.9 & 51.6 & 6.5 \\
\hline A4 & I am able to undertake periapical radiographs & 29.8 & 45.2 & 25.0 \\
\hline A15 & $\begin{array}{l}\text { I am able to perform non-surgical periodontal } \\
\text { treatment using appropriate methods }\end{array}$ & 10.5 & 23.4 & 66.1 \\
\hline A7 & $\begin{array}{l}\text { I am able to assess the treatment needs of patients } \\
\text { requiring orthodontics }\end{array}$ & 8.9 & 64.5 & 26.6 \\
\hline A8 & $\begin{array}{l}\text { I am able to formulate a comprehensive treatment plan } \\
\text { which addresses all treatment needs of my patients }\end{array}$ & 8.9 & 61.3 & 29.8 \\
\hline A12 & $\begin{array}{l}\text { I am able to carry out patients' treatment sessions in an } \\
\text { appropriate order }\end{array}$ & 8.1 & 47.6 & 44.4 \\
\hline A11 & $\begin{array}{l}\text { I am able to obtain a valid consent from my patients } \\
\text { prior to undertaking any treatment. }\end{array}$ & 7.3 & 19.4 & 73.4 \\
\hline A9 & $\begin{array}{l}\text { I am able to provide a range of treatment options to my } \\
\text { patients based on their individual circumstances }\end{array}$ & 6.5 & 58.9 & 34.7 \\
\hline A3 & I am able to prescribe appropriate dental radiographs & 4.0 & 45.2 & 50.8 \\
\hline A10 & $\begin{array}{l}\text { I am able to explain the merits and demerits of various } \\
\text { treatment options to my patients }\end{array}$ & 4.0 & 45.2 & 50.8 \\
\hline A13 & $\begin{array}{l}\text { I am able to prescribe drugs to my patients } \\
\text { appropriately }\end{array}$ & 3.2 & 61.3 & 35.5 \\
\hline A19 & $\begin{array}{l}\text { I am able to perform endodontic treatment on single } \\
\text { rooted teeth appropriately }\end{array}$ & 2.4 & 21.0 & 76.6 \\
\hline A2 & $\begin{array}{l}\text { I am able to undertake a comprehensive, clinical oral } \\
\text { examination }\end{array}$ & 1.6 & 37.1 & 61.3 \\
\hline A6 & $\begin{array}{l}\text { I am able to interpret common findings on dental } \\
\text { radiographs }\end{array}$ & 1.6 & 42.7 & 55.6 \\
\hline A23 & I am able to provide mechanically sound full dentures & 0.8 & 37.1 & 62.1 \\
\hline A1 & $\begin{array}{l}\text { I am able to obtain a complete medical history from my } \\
\text { patients. }\end{array}$ & 0.0 & 22.6 & 77.4 \\
\hline A14 & $\begin{array}{l}\text { I am able to administer inferior dental nerve blocks } \\
\text { effectively }\end{array}$ & 0.0 & 15.3 & 84.7 \\
\hline A16 & I am able to remove dental caries effectively & 0.0 & 17.7 & 82.3 \\
\hline A17 & $\begin{array}{l}\text { I am able to restore teeth with tooth coloured fillings } \\
\text { appropriately }\end{array}$ & 0.0 & 15.3 & 84.7 \\
\hline A18 & $\begin{array}{l}\text { I am able to restore teeth with amalgam fillings } \\
\text { appropriately }\end{array}$ & 0.0 & 14.5 & 85.5 \\
\hline A24 & $\begin{array}{l}\text { I am able to undertake non-surgical tooth extractions } \\
\text { appropriately }\end{array}$ & 0.0 & 18.5 & 81.5 \\
\hline
\end{tabular}


Table 2: Summary of response proportions as percentages for Part B

\begin{tabular}{|c|c|c|c|c|}
\hline Item & Question & $\begin{array}{l}\text { No } \\
\text { experience } \\
(\%)\end{array}$ & $\begin{array}{l}\text { Mostly } \\
(\%)\end{array}$ & $\begin{array}{l}\text { Always } \\
(\%)\end{array}$ \\
\hline B30 & I feel confident referring patients with suspected oral cancer & 50.8 & 30.6 & 18.5 \\
\hline B33 & $\begin{array}{l}\text { I am confident to evaluate new dental materials and products } \\
\text { using an evidence-based approach }\end{array}$ & 48.4 & 45.2 & 6.5 \\
\hline B34 & $\begin{array}{l}\text { I am confident to interpret the results of research which may } \\
\text { influence my practice }\end{array}$ & 34.7 & 56.5 & 8.9 \\
\hline B49 & $\begin{array}{l}\text { I feel able to raise concerns about inappropriate behaviour of } \\
\text { my colleagues }\end{array}$ & 23.4 & 48.4 & 28.2 \\
\hline B35 & I use an evidence-informed approach in my clinical practice. & 22.6 & 60.5 & 16.9 \\
\hline B42 & $\begin{array}{l}\text { I am able to manage the behaviour of children to enable } \\
\text { appropriate dental treatment }\end{array}$ & 10.5 & 70.2 & 19.4 \\
\hline B32 & $\begin{array}{l}\text { I have sufficient knowledge of scientific principles which } \\
\text { underpin my dental practice }\end{array}$ & 8.1 & 81.5 & 10.5 \\
\hline B44 & I maintain accurate records of my clinical notes & 7.3 & 66.1 & 26.6 \\
\hline B39 & $\begin{array}{l}\text { I feel confident to communicate potential risks of operative } \\
\text { procedures to patients }\end{array}$ & 4.8 & 56.5 & 38.7 \\
\hline B41 & $\begin{array}{l}\text { I feel confident managing anxious patients with appropriate } \\
\text { behavioural techniques }\end{array}$ & 4.8 & 76.6 & 18.5 \\
\hline B47 & I am aware of my legal responsibilities as a dental professional & 4.8 & 41.9 & 53.2 \\
\hline B29 & $\begin{array}{l}\text { I am able to refer patients with complex treatment needs } \\
\text { appropriately }\end{array}$ & 4.0 & 52.4 & 43.5 \\
\hline B45 & $\begin{array}{l}\text { I am able to work within the constraints of clinical appointment } \\
\text { schedules }\end{array}$ & 4.0 & 62.9 & 33.1 \\
\hline B38 & $\begin{array}{l}\text { I feel confident to address barriers to effective communication } \\
\text { with patients appropriately }\end{array}$ & 3.2 & 68.5 & 28.2 \\
\hline B48 & I restrict my relations with my patients to a professional level & 2.4 & 29.0 & 68.5 \\
\hline B25 & I feel I can manage people's expectations of their treatment & 1.6 & 86.3 & 12.1 \\
\hline B27 & I recognise my personal limitations in clinical practice & 1.6 & 58.9 & 39.5 \\
\hline B31 & $\begin{array}{l}\text { I reflect on my clinical practice in order to address my learning } \\
\text { needs }\end{array}$ & 1.6 & 68.5 & 29.8 \\
\hline B37 & $\begin{array}{l}\text { I provide opportunities for my patients to express their } \\
\text { expectations from dental treatment }\end{array}$ & 1.6 & 49.2 & 49.2 \\
\hline B26 & $\begin{array}{l}\text { I feel able to motivate my patients to encourage self-care for } \\
\text { their dental needs }\end{array}$ & 0.8 & 79.8 & 19.4 \\
\hline B28 & $\begin{array}{l}\text { I feel comfortable asking for help from supervisor or colleague if } \\
\text { needed }\end{array}$ & 0.8 & 38.7 & 60.5 \\
\hline B46 & I take responsibility for my continuing professional development & 0.8 & 60.5 & 38.7 \\
\hline B36 & I feel I can manage to communicate effectively with my patients & 0.0 & 50.8 & 49.2 \\
\hline B40 & $\begin{array}{l}\text { I feel confident to communicate appropriately with my } \\
\text { colleagues }\end{array}$ & 0.0 & 30.6 & 69.4 \\
\hline B43 & $\begin{array}{l}\text { I am able to fulfil my responsibilities as an effective member of } \\
\text { the dental team }\end{array}$ & 0.0 & 65.3 & 34.7 \\
\hline B50 & I take appropriate measures to protect patient confidentiality & 0.0 & 46.0 & 54.0 \\
\hline
\end{tabular}

*Items are ordered by the 'No experience' column in descending order. 


\section{References}

1. Cowpe J, Plasschaert A, Harzer W, Vinkka-Puhakka H, Walmsley AD. Profile and competences for the graduating European dentist - update 2009. Eur J Dent Educ. 2010;14(4):193-202.

2. General Dental Council. 2012. Preparing for practice-dental team learning outcomes for registration. London: General Dental Council.

3. Ali K, Tredwin C, Kay E, Slade A. Transition of new dental graduates into practice: a qualitative study. Eur J Dent Educ. 2016;20(2):65-72

4. Honey J, Lynch CD, Burke FM, Gilmour AS. Ready for practice? A study of confidence levels of final year dental students at Cardiff University and University College Cork. Eur J Dent Educ. 2011;15(2):98-103.

5. Ali K, Zahra D, McColl E, Salih V, Tredwin C. Impact of early clinical exposure on the learning experience of undergraduate dental students. Eur J Dent Educ. 2018; 22(1):e75-e80.

6. Lynch CD, Ash PJ, Chadwick BL, Hannigan A. Effect of community-based clinical teaching programs on student confidence: a view from the United kingdom. J Dent Educ. 2010; 74(5):510-6.

7. Divaris K, Barlow PJ, Chendea SA, Cheong WS, Dounis A, Dragan IF, Hamlin J, Hosseinzadeh L, Kuin D, Mitrirattanakul S, Mo'nes M, Molnar N, Perryer G, Pickup J, Raval N, Shanahan D, Songpaisan Y, Taneva E, Yaghoub-Zadeh S, West K, Vrazic D. The academic environment: the students' perspective. Eur J Dent Educ. 2008;12 Suppl 1:120-30.

8. Ali K, Jerreat M, Zahra D, Tredwin C. Correlations Between Final-Year Dental Students' Performance on Knowledge-Based and Clinical Examinations. J Dent Educ. 2017; 81(12):1444-1450.

9. Rodd HD, Farman M, Albadri S, Mackie IC. Undergraduate experience and selfassessed confidence in paediatric dentistry: comparison of three UK dental schools. Br Dent J. 2010 13;208(5):221-5.

10. Kumar M, Duncan HF. Radiographic evaluation of the technical quality of undergraduate endodontic 'competence' cases in the Dublin Dental University Hospital: an audit. J Ir Dent Assoc. 2012;58(3):162-6. 
11. Durham JA, Moore UJ, Corbett IP, Thomson PJ. Assessing competency in dentoalveolar surgery: a 3-year study of cumulative experience in the undergraduate curriculum. Eur J Dent Educ. 2007;11(4):200-7.

12. Ali K, Slade A, Kay E, Zahra D, Tredwin C. Preparedness of undergraduate dental students in the United Kingdom: a national study. $\mathrm{Br}$ Dent $\mathrm{J}$. $2017 ; 222(6): 472-477$

13. Gilmour AS, Welply A, Cowpe JG, Bullock AD, Jones RJ. The undergraduate preparation of dentists: Confidence levels of final year dental students at the School of Dentistry in Cardiff. Br Dent J. 2016; 221(6):349-54.

14. Manakil J, George R. Self-perceived work preparedness of the graduating dental students. Eur J Dent Educ. 2013;17(2):101-5.

15. Hook CR, Comer RW, Trombly RM, Guinn JW 3rd, Shrout MK. Treatment planning processes in dental schools. J Dent Educ. 2002;66(1):68-74.

16. Ayers KM, Thomson WM, Al-Hassiny H, Rich AM, Newton JT. A qualitative investigation of the experiences of immigrant dentists working in New Zealand. N Z Dent J. 2008;104(3):97-103.

17. Bissell V, Chamberlain S, Davenport E, Dawson L, Jenkins S, Murphy R. The Overseas Registration Examination of the General Dental Council. Br Dent J. 2016;221(5):257-61.

18. Boorberg NB, Schönwetter DJ, Swain VL. Advanced placement, qualifying, and degree completion programs for internationally trained dentists in Canada and the United States: an overview. J Dent Educ. 2009;73(3):399-415

19. Ali K, Slade A, Kay EJ, Zahra D, Chatterjee A, Tredwin C. Application of Rasch analysis in the development and psychometric evaluation of dental undergraduates preparedness assessment scale. Eur $J$ Dent Educ. 2017;21(4):e135-e141.

20. Postma TC, White JG. Students' perceptions of vertical and horizontal integration in a discipline-based dental school. Eur J Dent Educ. 2017 May;21(2):101-107.

21. Stewardson DA, Shortall AC, Lumley PJ. Endodontics and new graduates, Part 2: Undergraduate experience and course evaluation. Eur J Prosthodont Restor Dent. 2003;11(1):15-21. 
22. Ribeiro DM, Réus JC, Felippe WT, Pacheco-Pereira C, Dutra KL, Santos JN, Porporatti AL, De Luca Canto G. Technical quality of root canal treatment performed by undergraduate students using hand instrumentation: a metaanalysis. Int Endod J. 2018;51(3):269-283.

23. Ellaway $\mathrm{RH}$, Graves L, Cummings BA. Dimensions of integration, continuity and longitudinality in clinical clerkships. Med Educ. 2016 Sep;50(9):912-21.

24. Harden RM. Outcome-based education: the future is today. Med. Teach. 2007; 29 (7):625-629.

25. Chambers DW. Dental curriculum and accreditation--means, ends, and the continuum. J Dent Educ. 1996; 60 (10): 816-820.

26. Leach DC. Competence is a habit. JAMA. 2002; 287 (2): 243-244.

27. Uti OG, Fashina AA. Oral cancer education in dental schools: knowledge and experience of Nigerian undergraduate students. J Dent Educ. 2006;70(6):67680.

28. Burzynski NJ, Rankin KV, Silverman S Jr, Scheetz JP, Jones DL. Graduating dental students' perceptions of oral cancer education: results of an exit survey of seven dental schools. J Cancer Educ. 2002;17(2):83-4.

29. Nieminen P, Virtanen Jl. Information retrieval, critical appraisal and knowledge of evidence-based dentistry among Finnish dental students. Eur J Dent Educ. 2016. doi: 10.1111/eje.12203.

30.Straub-Morarend CL, Wankiiri-Hale CR, Blanchette DR, Lanning SK, Bekhuis T,Smith BM, Brodie AJ, Oliveira DC, Handysides RA, Dawson DV, Spallek H. Evidence-Based Practice Knowledge, Perceptions, and Behavior: A MultiInstitutional, Cross-Sectional Study of a Population of U.S. Dental Students. J Dent Educ. 2016;80(4):430-8.

31. Barnsley L, Lyon PM, Ralston SJ, Hibbert EJ, Cunningham I, Gordon FC, Field MJ. Clinical skills in junior medical officers: a comparison of self-reported confidence and observed competence. Med Educ. 2004;38(4):358-67.

32. Lai NM, Teng CL. Self-perceived competence correlates poorly with objectively measured competence in evidence based medicine among medical students. BMC Med Educ. 2011; 11:25.

33. Henzi D, Davis E, Jasinevicius R, Hendricson W. In the students' own words: what are the strengths and weaknesses of the dental school curriculum? J Dent Educ. 2007 May;71(5):632-45 


\section{Appendix : Dental Undergraduates Preparedness Assessment Scale}

\begin{tabular}{|c|c|c|}
\hline \multicolumn{3}{|l|}{ Part A } \\
\hline 1. & \multicolumn{2}{|l|}{ I am able to obtain a complete medical history from my patients. } \\
\hline 2. & \multicolumn{2}{|l|}{ I am able to undertake a comprehensive, clinical oral examination } \\
\hline 3. & \multicolumn{2}{|l|}{ I am able to prescribe appropriate dental radiographs } \\
\hline 4. & \multicolumn{2}{|l|}{ I am able to undertake periapical radiographs } \\
\hline 5. & \multicolumn{2}{|l|}{ I am able to undertake bitewing radiographs } \\
\hline 6. & \multicolumn{2}{|l|}{ I am able to interpret common findings on dental radiographs } \\
\hline 7. & \multicolumn{2}{|l|}{ I am able to assess the treatment needs of patients requiring orthodontics } \\
\hline 8. & \multicolumn{2}{|c|}{$\begin{array}{l}\text { I am able to formulate a comprehensive treatment plan which addresses all treatment needs of my } \\
\text { patients }\end{array}$} \\
\hline 9. & \multicolumn{2}{|c|}{$\begin{array}{l}\text { I am able to provide a range of treatment options to my patients based on their individual } \\
\text { circumstances }\end{array}$} \\
\hline 10 & \multicolumn{2}{|c|}{ I am able to explain the merits and demerits of various treatment options to my patients } \\
\hline 11 & \multicolumn{2}{|c|}{ I am able to obtain a valid consent from my patients prior to undertaking any treatment. } \\
\hline 12 & \multicolumn{2}{|l|}{ I am able to carry out patients' treatment sessions in an appropriate order } \\
\hline 13 & \multicolumn{2}{|l|}{ I am able to prescribe drugs to my patients appropriately } \\
\hline 14 & \multicolumn{2}{|l|}{ I am able to administer inferior dental nerve blocks effectively } \\
\hline 15 & \multicolumn{2}{|c|}{ I am able to perform non-surgical periodontal treatment using appropriate methods } \\
\hline 16 & \multicolumn{2}{|l|}{ I am able to remove dental caries effectively } \\
\hline 17 & \multicolumn{2}{|l|}{ I am able to restore teeth with tooth coloured fillings appropriately } \\
\hline 18 & I am able to restore teeth with amalgam fillings appropriately & \\
\hline 19 & I am able to perform endodontic treatment on single rooted teeth ap & \\
\hline 20 & I am able to perform endodontic treatment on multi rooted teeth app & \\
\hline 21 & I am able to provide crowns using principles of tooth preservation & \\
\hline 22 & I am able to provide mechanically sound partial dentures & \\
\hline 23 & I am able to provide mechanically sound full dentures & \\
\hline 24 & I am able to undertake non-surgical tooth extractions appropriately & \\
\hline Part B & & \\
\hline 25. & I feel I can manage peoples' expectations of their treatment & \\
\hline 26. & I feel able to motivate my patients to encourage self-care for the & eds \\
\hline 27. & I recognise my personal limitations in clinical practice & \\
\hline 28. & I feel comfortable asking for help from supervisor or colleague if & \\
\hline 29. & I am able to refer patients with complex treatment needs approp & \\
\hline 30. & I feel confident referring patients with suspected oral cancer & \\
\hline 31. & I reflect on my clinical practice in order to address my learning $n$ & \\
\hline 32. & I have sufficient knowledge of scientific principles which underpi & practice \\
\hline 33. & I am confident to evaluate new dental materials and products usi & ence-based approach \\
\hline 34. & I am confident to interpret the results of research which may infl & oractice \\
\hline 35. & I use an evidence-informed approach in my clinical practice. & \\
\hline 36. & I feel I can manage to communicate effectively with my patients & \\
\hline 37. & I provide opportunities for my patients to express their expectati & ental treatment \\
\hline 38. & I feel confident to address barriers to effective communication w & appropriately \\
\hline 39. & I feel confident to communicate potential risks of operative proce & atients \\
\hline 40. & I feel confident to communicate appropriately with my colleague & \\
\hline 41. & I feel confident managing anxious patients with appropriate beh & chniques \\
\hline 42. & I am able to manage the behaviour of children to enable approp & I treatment \\
\hline 43. & I am able to fulfil my responsibilities as an effective member of $t$ & eam \\
\hline 44. & I maintain accurate records of my clinical notes & \\
\hline 45. & I am able to work within the constraints of clinical appointment $\mathrm{s}$ & \\
\hline 46. & I take responsibility for my continuing professional development & \\
\hline 47. & I am aware of my legal responsibilities as a dental professional & \\
\hline 48. & I restrict my relations with my patients to a professional level & \\
\hline 49. & I feel able to raise concerns about inappropriate behaviour of my & \\
\hline 50. & I take appropriate measures to protect patient confidentiality & \\
\hline & Response Categories & Numerical Score \\
\hline & Part A No Experience & 0 \\
\hline & With verbal and / or practical input from a colleague & 1 \\
\hline & On my own, independently & 2 \\
\hline & Part B No Experience & 0 \\
\hline & Mostly & 1 \\
\hline & Always & 2 \\
\hline
\end{tabular}

